\title{
THE BLACK SEA \& TURKISH STRAITS AFTER 2023: THE END OF LAUSANNE \& PROSPECTS FOR TURKEY'S FUTURE AS REGIONAL POWER
}

\author{
Dr. Rani Erum \\ Department of Political Science \\ Federal Urdu University, Karachi - Pakistan \\ rani.irum@fuuast.edu.pk \\ https://orcid.org/0000-0002-3845-8899
}

\begin{abstract}
Turkey always caught the attention of the world not only at the time of the Ottomans but even after their demise the geo-strategic location of its territory gives it a significant position in world politics. The only sea opening for five Eurasian states and juncture of Europe and Asia made it a game-changer in the future just like in the era of the Cold war when NATO immediately installed nuclear weapons and directed to the former USSR from the Incirlik US military Air Base in 1962 and change the entire situation. Similarly, the Black Sea and Turkish Straits played a very important role not only for host nations but for many others. The research is intended to understand the importance of the region for them and the world and what future changes can occur due to the end of the international peace treaty of Lausanne after completing 100 years. Turkey has a very glorify past which they are claiming to get again after 2023, thus respective easy also envisioned the prospects of their claim as well as enlightened the challenges which Ankara has to face during this process.
\end{abstract}

KEYWORDS: Geo-Strategic location, Maritime Shipping, International Straits, Old Glory, Demilitarization, Navigation rights,

\section{INTRODUCTION}

Turkey, The Black Sea and, the Turkish straits are situated on a very important geostrategic place where Europe meets Asia and landlock countries met their only harbors.

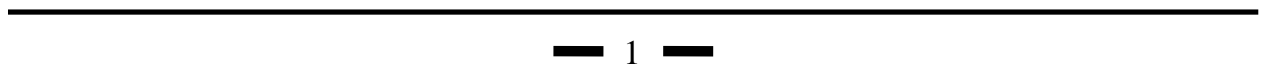




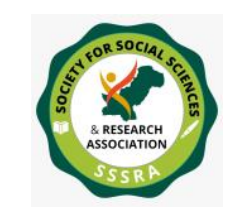

The Black Sea \& Turkish Straits after...

This geographic significant placed this junction point on a very high place in world politics. Since the beginning of modern history, this region became a center of attraction for many dynasties, thus several wars had been fought for its acquisition, finally in the $17^{\text {th }}$ century Ottomans occupy almost completely the whole region. the Black sea was known then as the Ottomans sea lake where only the Tsar's of Russia often challenge them otherwise it was only in the use of Turk-authorize merchants for trade.

Ottomans were defeated in World War I and lost all their territories to Great powers. Victorious powers decided to take all lands except the region of Anatolia where the Turk race was in majority. They also took control of the connected sea and tributaries. All of these decisions were taken in the peace treaty of Severe in 1920 by Great powers including United Kingdom, France, Italy and, others. The worst part of this treaty was that there was no representation of turkey, which showed the animosity and rage against losing power and humiliated treatment. Turkey refuses to accept the treaty and protest against humiliating terms and conditions imposed upon the great Empire of its time. In 1923 another conference was conducted by victorious powers in Lausanne, France to settle the matters with Turks. The only visible difference between Severe and Lausanne was that this time Turks were present to hear the decisions of their future. Thus Treaty of Lausanne was signed and accepted by new nationalist Turkey which was restricted only in the region of Anatolia and a small area of Istanbul placed in Europe. The treaty also accepts some authority on both Bosphorus and Dardanelle straits only related to merchandising and trade. The Straits declare as an International maritime route thus any kind of military installation was banned as well as no extra regulation was allowed to impose on shipping. These were quite hostile terms because straits flowed between the Turk territory and they should have the right to use it to their benefit. The straits regulations increase their finance and they can also get rid of the financial debt of war. Although later the Montreux convention of 1936 provides them some ease and control on Straits. Turkish believed that Lausanne was the main culprit which deteriorated their status. The treaty will expire in 2023, President Erdogan is very enthusiastic about the bright future of his homeland and believes to retain their old glory but analysts have other opinions regarding the acquisition of the Black Sea, complete control over Straits, and, gaining lost territories. The research intended to get answers to all these queries therefore it started with the basic geographic understanding and leads towards the complicated misconceptions.

\section{GEOGRAPHIC LOCATION OF BLACK SEA AND TURKISH STRAIT}

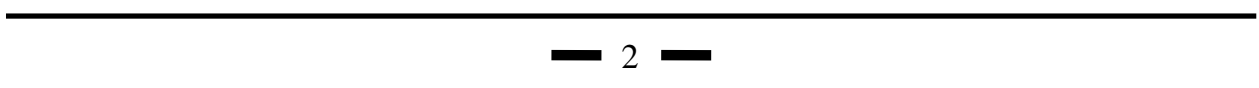


The Black Sea is the land lock sea that has only one accesses point which is known as the Bosphorus strait. The sea is surrounded by Bulgaria, Georgia, Romania, Russia, Turkey,

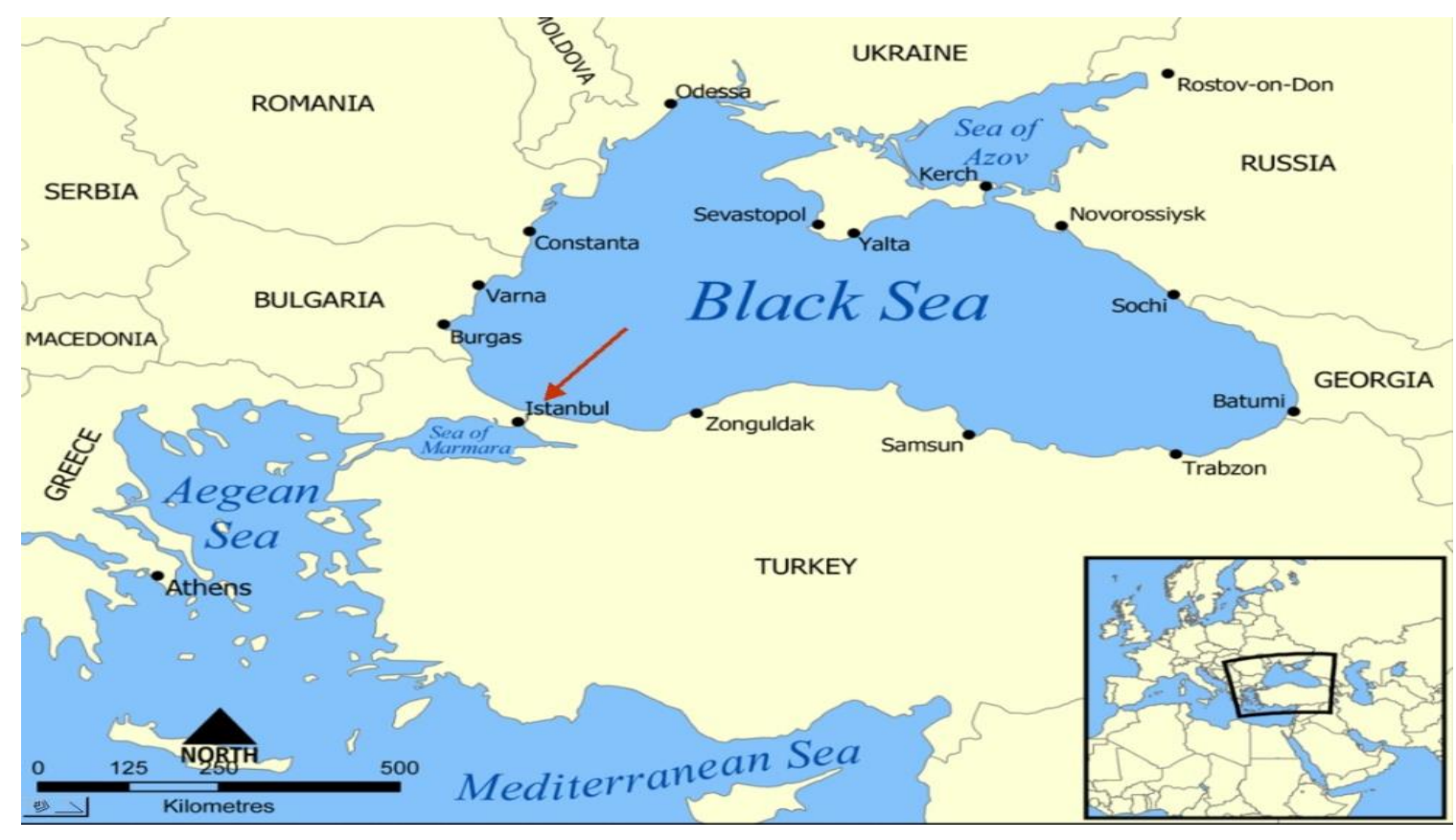

and Ukraine. It is roughly 730 miles widespread from west to east and has $168,500 \mathrm{sq}$ miles surface area. There are 8 major rivers (Namely the rivers are: Danube, Dnieper, Southern Bug, Dniester, Don, Kuban, Rioni, and Kizilirmak) flow into it, and effectually connecting coastal states, as well as Moldova, Germany, Austria, Slovakia, Hungary, Croatia, Serbia, and Belarus (Encyclopedia Britannica). It also provides the only warm water coastal area to Russia.

Whereas, Bosphorus or Istanbul strait and the Dardanelles Strait created the Turkish Straits which is nearly a 31kilometers long waterway connecting the Sea of Marmara and the Black Sea. (Istikbal, May 2001: 76-85). The Bosporus has a very narrow and curved structure in comparison to other international straits. In the northern entrance, its maximum width is about 3,600 meters and in the southern entrance, its narrowest place is only 698 meters (Oral \& Ozturk, 2006: 05). This strait connected the European and Asian parts of Turkey. The physical role and its features suggested that it is the most dangerous and challenging waterway in the world. (Black sea and Turkish strait map retrieved from https://maritimecyprus.com/2021/03/28/guidelines-for-transiting-the-turkish-straits/).

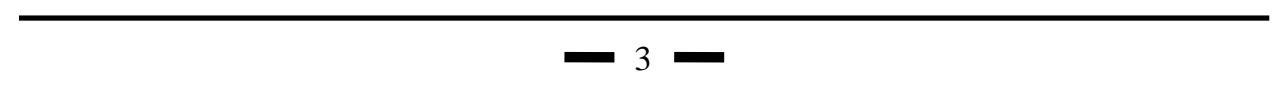




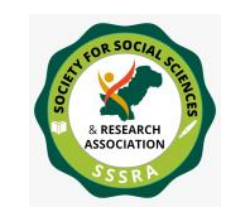

Pak. Journal of Int'L Affairs, Vol 4, Issue 3 (2021)

The Black Sea \& Turkish Straits after...

\section{SIGNIFICANCE OF TURKISH STRAITS FOR BLACK SEA NATIONS}

The Black Sea and Turkish Straits have played a significant geopolitical role. Their importance is marked from ancient Greece till date. The geographical location gives them strategic importance not only for coastal countries but also to the world. Particularly in the $21^{\text {st }}$ century, the shift in power dynamics between the Russian Federation, Turkey, and the West placed it in an undeniable position.

The significance of the Black Sea and Turkish Straits increased in modern maritime shipping due to a wide range of goods transporting to the global market and place it in a very vital position. The most valuable are the energy products of Russia, Ukraine, and Turkey. It is used for supplying oil and natural gas via pipelines from the Caspian Sea and then transport by ships. The Black Sea itself has vast amounts of oil and natural gas resources.

All its coastal states have capitalized on these reserves. Therefore on one hand energy issues arise because it is shared by six nation-states, and on the other hand the region frequently faces typical geopolitical issues like territorial waters, economic exclusive zones as well as fishing rights. Moreover, the Russian seizure of Crimea from Ukraine in 2014 radically reformed the land map of the region, adding almost ten thousand square miles to its territory which also brought a change in the Federation's territorial waters and EEZ in the Black Sea.

\section{TURKEY AND TURKISH STRAITS}

Turkish Strait was coming under Ottoman control in 1453 when Mehmet II conquered Constantinople (Istanbul), since then it was ruled by generations of ottomans till the end of World War I when it was taken by great powers (Harl, 2017:45). Modern Turkey was established from the wrecks of the Ottoman Empire, though the conversion from an old realm to a new state was not an easy task. The modified borders were not defined until the Treaty of Lausanne was signed in 1923. Turkey was left with only that land which the world can see on a map today, though governing both European and Asian sides of the Straits but with lots restrictions, on the other hand, World War I had left them in miserable economic and defenseless condition (Cagaptay, 2014: 05). They were in many ways unable to declare their authority over their land, specifically the Straits, in an international forum. The Black Sea was known as Turkish lake for ages because of complete control of Ottomans of its surrounded regions thus it never became an issue for Turks to how they contain their sovereignty on the straits but after the treaty of Lausanne,

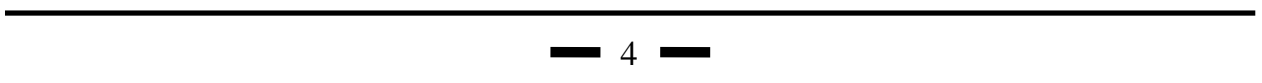




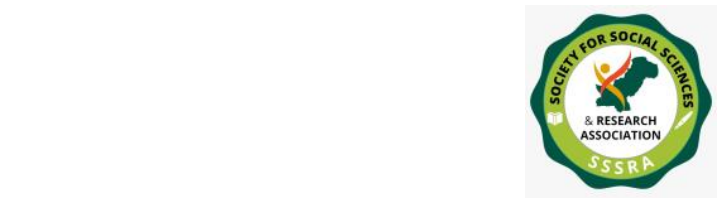

Pak. Journal of Int'L Affairs, Vol 4, Issue 3 (2021)

The Black Sea \& Turkish Straits after...

Turkish were seems reluctant to claimed over the straits anyhow the treaty forced them to wakeup and proclaimed their legal right which they sustain in Montreux convention in1936.

\section{TREATY OF LAUSANNE \& THE CHANGING STATUS OF TURKEY}

The Treaty of Lausanne was the continuation of the Treaty of Severe (1920) which was not accepted by Turkey because of the absence of their representative and its hostile clauses but with immense pressure, sick men of Europe had no other choice to the signed subsequent treaty of Lausanne in 1923. the basic goal of the treaty was to dealt remains of the Ottomans and withholding peace after a long deadly war. The first two sections were related to New Turkey as;

Section I: It defines the new borders between the new state of Turkey and its neighbors. Section II: "regarding the regime of straits", precisely about the status of the Dardanelles and Bosporus Straits.

The Lausanne Convention of 1923 provided free navigation for the Turkish Straits, demilitarized the area, established a special Straits Commission, and most importantly allowed passage of foreign war vessels. Rozakis believes that this convention is a turning point. Before the Treaty only two basic international rules were regularly recognized by the Ottoman Empire and the great powers which were, freedom of passage for merchant ships and closure to warships in times of peace (Rozakis \& Stagos, 1987: 87).

This treaty bounded the new nationalist Turk regime with invisible chains because article 6 forced it to demilitarize the strait and allow foreign naval vessels to move there as well restricted Turkey to install not even any firepower in the particular zone. Whereas, only nominal security was allowed by Article 8 around Istanbul which was still the capital of Turkey. The treaty was a major setback to Turkey because it officially ended their control of the Straits and turned it into an international strait.

After a while, other defeating axis powers challenging their treaties and violating their clauses such as Germans starting to rebuild their military and Italy occupied Ethiopia in 1935. These events encouraged the Turk regime to vocal on straits control. On $10^{\text {th }}$ April 1936, they send an official note to all members of the treaty and recalling the international concept of "rebus ric stantibus"(a legal principle that permits the override of a treaty due to a basic change in the situations of the place (Encyclopedia Britannica). It was an opportunity for Turkey to get back their control over the straits therefore it did

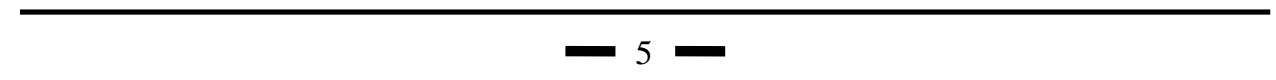




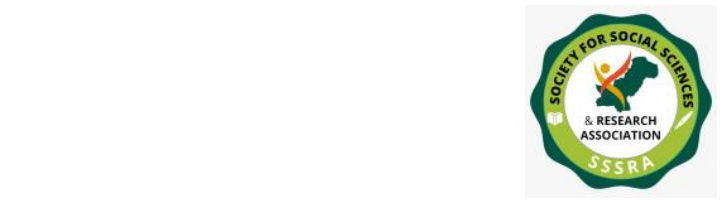

Pak. Journal of Int'L Affairs, Vol 4, Issue 3 (2021)

The Black Sea \& Turkish Straits after...

the appropriate measures, the rest of the participants of the treaty agree to meet for negotiations in Montreux.

\section{THE MONTREUX CONVENTION 1936}

The convention was held on $22^{\text {nd }}$ June 1936 in the Swiss town of Montreux on the future of Turkish Straits which were to accept of Italy all members of the former treaty participated. Almost after a month on $20^{\text {th }}$ July, a new treaty was signed (Nolte, 2013). The new treaty was divided into five sections, 29 articles, and four annexes (Ibid). The new treaty accepted some authority of the Turkish regime in an area of strategic, political, and economic importance. It was also created a practical balance among all Black Sea nations. Montreux convention was the first effort that was purely for peaceful purposes. It does not include regulatory provisions that mean it allowed turkey to authorize to regulate the navigation in its jurisdiction by its law and it cannot be challenged by any using state. It remained unchallenged to date. Turkey controls both the east and west sides of the Straits, all nations, including global naval powers, are following the terms of the treaty, like other cosignatories. Thus, the Montreux convention provided a median way to resolve the issues of 6 close-knitted states.

\section{TURKISH STANCE ON BLACK SEA \& STRAITS}

Today Turkey is focused largely on the Bosphorus and Dardanelles, security at least from a military perspective. Apart from Russia Turkey is the only state with a sizeable navy that can challenge the Russian Black Sea fleet. Instead of challenging the Russian regime happy to make cordial relations with the Turkish regime and providing military equipment and other hardware (Balcer, July 2014: 1-9). Turkey knows its significant position in the region therefore it capitalized it against regional nations as well as in front of major powers. It also understands that after 2023 region looking up to change in the stance and the policies of Ankara particularly on the Straits access and increase militarization on entrance points. It also realizes that International law won't allow it to do any major modification in the present navigation regulations of the straits. Turkey also wanted to see how NATO and the US urged to hold their strong position in the region with holding Incirlik airbase without providing full F35 program to it (Jhonson \& Garner, $19^{\text {th }}$ July 2019). However, the substantial development in the US-Russian relations in recent years lowered the importance of the Incirlik airbase for Washington but they won't like to lose their position thus Turkey's strategic value will not be dropped by any means. Turkey would also like to impose some more regulations and taxes after 2023 on general navigation shipping to increase their finances as well as will install more projects to gain more revenue. 


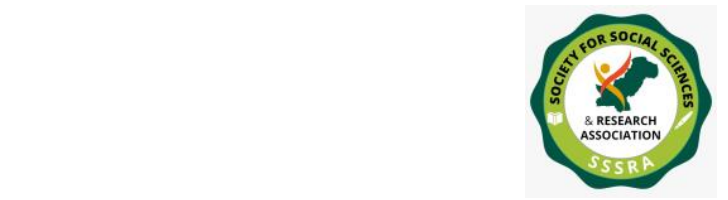

The Black Sea \& Turkish Straits after...

Turkey also has many environmental concerns on dense trafficking of ships through straits which resulting in severe ecological issues. In the past few years, vessel trafficking increased with numbers and in size. Cargo style is also hugely changed, particularly oil products carrying tankers drop the vast amount of hazardous waste during the shipping. This congested maritime traffic caused marine pollution around both straits which not only demolished a large number of sea life as well as causing a deadly effect on people who lived in the surroundings. It resulted in the extinction of many fish species and the devastation of a natural ecosystem. Thus Turkey wanted to control the quantity of shipping which they might be able after 2023 .

\section{RUSSIAN STANCE}

After the annexation of Crimea in 2014 Russian coastal area increase almost double from the previous portion of the territory which increased water territory, therefore, Moscow has now more sea territory for drilling, fishing, and it also increases its EEZ means more security measures (Dremliuga, 2015). They also understand the reality of the region and the key strategic position of turkey as well as realizes the fact of only the warm water coast they have thus, the Putin regime does not want any unprecedented conflict with Turkey. Russian improve its bilateral relations with Ankara in recent times and increased military deals as well as other technological goods. They wanted fluent oil products trafficking from the straits hence, do not interested to create any kind of security challenge for Turkey.

\section{OTHER BLACK SEA NATIONS STANCE}

Bulgaria, Rumania, Ukraine and, Georgia are less capable military nations in comparison to Russia and Turkey. These states have more focus is related to smooth trade shipping without any hurdle through the Turkish Straits because it is the only access point for them and their economy largely dependent on the maritime trade. Their security concerns increase only after the illegal annexation of Crimea by Russia, since, then some of the countries like Romania and Georgia, are thinking of having join base with the US to handle such misconducts of major powers of the region. Both states have stated a desire for profound mutual armed collaboration with the United States. Romania has been keen to host an enduring U.S. base on their land as it would be seen as a chief development to their security state (Romania Insider, $5^{\text {th }}$ Feb 2018). Both Nations offering their bases in the Black Sea such as Mihail Kogălniceanu Air Base in Romania, or Vaziani Military Base in Georgia but this is still only news. The reason behind The US not being vocal on such desires is because the Incirlik airbase is the mutual base of both nations and also in

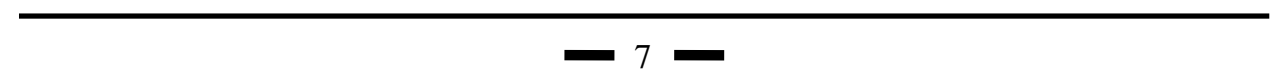




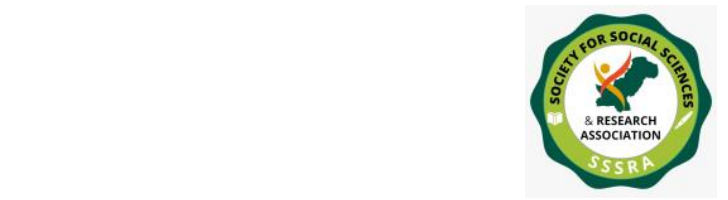

Pak. Journal of Int'L Affairs, Vol 4, Issue 3 (2021)

The Black Sea \& Turkish Straits after...

the use of NATO as Turkey is the member of the alliance therefore, it is not in the US interest to end its alliance with such an important power of the region.

\section{EUROPEAN STANCE}

The West has various interests and responsibilities in the Black Sea region. After joining the European Union in 2007 by Romania and Bulgaria, the EU was protracted to the Black Sea. Since then EU is reliant on the transportation of energy through this region and has an interest in safeguarding the stability of the route. European companies have many financial interests in the region because it provides them the shortest route to the energy sources producing the Caspian zone. Since 2007 Black Sea is also considered the European portion. Therefore EU has also eyeing 2023 and the future policies of turkey.

\section{TURKEY'S AMBITIONS AFTER 2023}

The end of the treaty of Lausanne in 2023 has begun a new discussion between global analysts about what will be the course of action of Turkish after the expiration of this legal binding on it. President Recep Tayyib Erdogan had stated in the 2019 republic ceremony that something groundbreaking will happen from the Turkish side after 2023. He also indicated that Turkey will reorganize the region and will achieve new heights as it was had at the time of the Ottomans. Erdogan has a particular opinion on peace treaties with Turkey after WWI. He believed that both Severe and Lausanne were the forced agreements and his nation and leaders had no choice except to agree on them. His country had to accept the abandonment of the islands in the Aegean Sea against Greece. He believed that these treaties were the dagger in the back of the Turk nation.

The Turkish nation also believed that they work hard to get rid of those bruises given by victorious powers of WWI to them. They had not only taken the large territories from them and given them freedom without the consent of Turkey but also restricted Turkey on its waters. Like it could not impose navigation rules, taxes and, judicial actions around Turkish straits. According to International Law, every treaty expires after 100 years, thus in 2023 Lausanne will end and Turkey will be free to drill in Black Sea to get more oil, as well as can build new channels to connect Marmara and the Black sea, open new military stations and change the power domain in the region. On 98 the anniversary of Modern Turkey Erdogan said;

"We are determined to enter 2023, when we will celebrate the 100th anniversary of our republic, as a stronger, more independent, and more prosperous country economically, militarily, politically, and diplomatically," he also added, "We continue to thwart the 


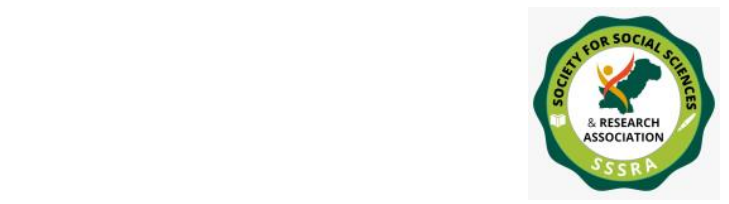

The Black Sea \& Turkish Straits after...

treacherous ambitions against our country's unity and integrity, and the peace, and wellbeing of our nation," (Gundogan, 24.07.2021).

He also indicated that Turkey will not tolerate any blackmailing or intimidation by any circle and will defend its legal international rights. The tone of the Turkish president suggested that the government has a plan and they will be eager to pursue it with full conviction and force. Erdogan said earlier that he wanted to see his country in the top 10 economies as he presented vision 2023. It is the 10-year program that transforms the country into a stable, independent, and financially self-dependent strongly secure regional power.

To achieve this massive task he introduces many mega projects such as the GebzeOrhangazi-Izmir Highway which reduces the 8-hour journey and, shifted the mass trade from Istanbul to the narrow Marmara region. Today Turkey placed in $16^{\text {th }}$ position in World's economy. He desired to enter the G10 nations with the \$2.6 trillion GDP and \$2500 Per Capita also reducing unemployment from 11\% to 5\% (Al-Hussein, Feb 2018). He also envisioned Istanbul as a world's financial hub like Singapore or London.

Turkey's energy sector is $75 \%$ dependent on fossil fuels, whereas, it imports $40 \%$ of its coal and, $100 \%$ natural gas and crude oil from other countries (Wójcik, 27 ${ }^{\text {th }}$ Aug 2020). It Imports 53\% of gas from Russia and the rest from Iran. Turkey wanted to reach the hydrocarbon resources of the Aegean and the Black Sea and it only can happen when the maritime territories have changed. After becoming President Erdogan has taken wide proactive actions in the Mediterranean and the Levant region, analysts believed that his actions have resembled with great Ottomans particularly along with Syrian borders, people also claimed that he pursue Turkish ambition to become a regional power. Ankara also maintains its gunboat diplomacy as a strategy for fishing, drilling and, sometimes sending a small vessel to pressurize Greece and Cyprus by its presence (Rose, $30^{\text {th }}$ Sep 2020). Turk people also believed that their maritime territory should be expanded and the terms should be renegociate which shows the vision of common Turk to claim their past status again. Thus most of the scholars called it Turkish neo-Ottoman policy.

\section{CONCLUSION}

The Montreux Convention is the basic tool to maintain the security of Turkish straits and the Black Sea until it exists no major change can happen in the rules and regulations. If any state tries to terminate it created instability and uncertainty which is not only causing 


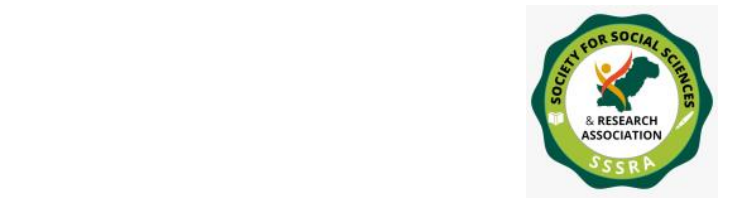

issues for Turkey and other Black Sea Nation. Thus Turkish control and jurisdictional powers would continue after 2023 and high sea waters of the Black Sea would be outside of Turkey's jurisdiction. The geopolitical structures of both the Turkish Straits and the Black Sea will secure their crucial role between Asia and Europe. Turkey's policies are also described as the country's weaving between the East and the West.

The vision beyond 2023 and neo-Ottoman ambitions of Erdogan are still out of reach as statistics explain although their armed actions in Northern Syria give weight to the regime it would not create fascinating possibilities of re-emergence of an Empire. On the other side, the Black Sea has the presence of Russian force and NATO, both of them would not like to change the balance of power in the Black Sea.

Turkey also showed a keen interest in using both government and society that advocated the political Islam ideology, with Muslim norms brought into public life. Ankara on one side using ideological sources and on the other side uses all active measures to achieve the path of old glory. It enforces the defense department by increasing military capacity. Erdogan wants its place under the sun - and will pursue autonomous policies in the region. His ambition is to get what they lost one century ago. The hard task which he faces is the factual gap between his ambitions and, the reality of the world. He has built the strong foundations of Turkey with the belief that his country will achieve its lost status. 


\section{REFERENCES}

Al-Hussein, M. Hussain, (12 ${ }^{\text {th }}$ Feb 2018) Vision 2023: Turkey and the post-Ottoman anniversary, https://www.middleeastmonitor.com/20180212-vision-2023-turkey-and-the-postottoman-anniversary/(Retrieved: 22.08.2021)

Balcer, A. (2014, July). Dance with the Bear: Turkey and Russia After Crimea. Global Turkey in Europe, Working Paper 08, pp. 1-9.

Cagaptay, Soner (2014) The rise of Turkey: the twenty-first century's Muslim Power, Nebraska: Potomac Books.

Dremliuga, R. (2015). The Development of the Black Sea Straits Regulation of International Navigation. Asian Social Science, Vol. 11, No. 12, pp. 269-273.

Encyclopedia Britannica, https://www.britannica.com/topic/rebus-sic-stantibus

Encyclopedia Britannica https://www.britannica.com/place/Black-Sea (Cited: 16.08.2021)

Gardiner, R. K. (2015). Treaty Interpretation. New York: Oxford University Press.

Gundogan, Baris (24.07.2021) Turkish President Marks $98^{\text {th }}$ anniversary of Lausanne Treaty, $\quad$ https://www.aa.com.tr/en/politics/turkish-president-marks-98thanniversary-of-lausanne-treaty/2313115(Retrieved: 12.08.2021)

Harl, Kenneth, W. (2017) The Ottoman Empire, USA: The Great Courses

Istikbal, C. (2001, May 12-14). Regional Transport Demands and Safety of Navigation in Turkish Straits: A Balance at Risk. Problems of Regional Seas 2001; Proceedings of the International Symposium on the Problems of Regional Seas, pp. 76-85. 
Johnson, K., \& Gramer, R. (2019, July 19). Who Lost Turkey? Retrieved from https://foreignpolicy.com/2019/07/19/who-lost-turkey-middle-east-s-400-missiledeal-russia-syria-iraq-kurdishunited-states-nato-alliance-partners-alliesadversaries/.

Nolte, G. (2013). Treaties and Subsequent Practice. Oxford: Oxford University Press

Oral, N \&Ozturk, B. (2006) The Turkish Straits: Maritime Safety, Legal Environmental Aspects, Istanbul: Turkish Marine Research Foundation Press

Romania Insider. (2018, February 5). The Romanian defense minister wants a permanent US presence at a local military base. Retrieved from https://www.romaniainsider.com/us-presence-local-military-base(cited: 12.08.2021)

Rose, Caroline, D. (30 ${ }^{\text {th }}$ Sep 2020) As Turkey's Economy Goes, So Goes Its Ambitions: Dire economic straits have forced the ruling party to reconsider its plans. https://geopoliticalfutures.com/as-turkeys-economy-goes-so-goes-its-ambitions/ (Retrieved: 18.08.2021)

Rozakis, C. L., \& Stagos, P. (1987) The Turkish Straits, Athens: Martinus Nijhoff Publishers

Turkish Straits, https://www.mfa.gov.tr/the-turkish-straits.en.mfa (Retrieved: 12.08.2021)

Treaty of Peace with Turkey Signed at Lausanne (1923). Lausanne. Retrieved from https://wwi.lib.byu.edu/index.php/Treaty_of_Lausanne(Retrieved: 20.08.2021)

Wójcik, Jan (27 ${ }^{\text {th }}$ August 2020) Turkey: In Search of Energy to Fulfil Geopolitical Ambitions, Warsaw: Warsaw Institute review. https://warsawinstitute.review/issue-22020/turkey-in-search-of-energy-to-fulfil-geopolitical-ambitions/(Retrieved: 19.08.2021) 